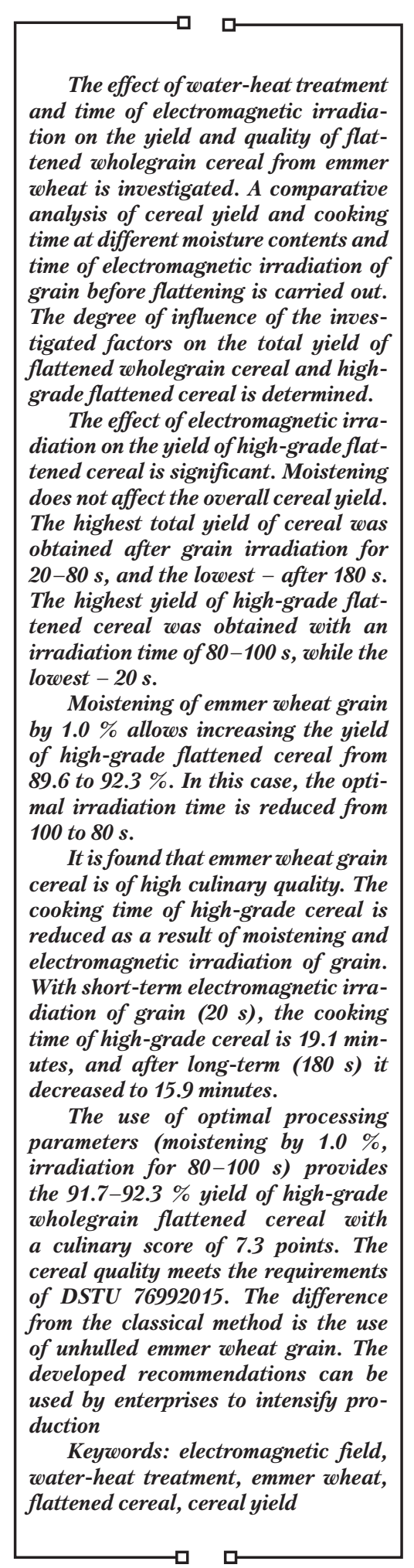

Received date 27.09.2020

Accepted date 19.11.2020

Published date 21.12.2020
UDC 641.53.092:683.958:664.71-11

DOI: $10.15587 / 1729-4061.2020 .217018$

\section{EFFECT OF ELECTROMAGNETIC IRRADIATION OF EMMER WHEAT GRAIN ON THE YIELD OF FLATTENED WHOLEGRAIN CEREAL}

\author{
N. O sokin a \\ Doctor of Agricultural Sciences, Professor* \\ V. Li u b y c h \\ Doctor of Agricultural Sciences, Professor* \\ V. Novikov \\ $\mathrm{PhD}$, Senior Lecturer* \\ E-mail: 1990vovanovikov1990@gmail.com \\ I. Leshchenko \\ Postgraduate Student* \\ V. Petrenko \\ $\mathrm{PhD}$
}

Laboratory of Grain Milling and Bakery Technology Institute of Food Resources National Academy of Agrarian Sciences Eugene Sverstyuk str., 4a, Kyiv, Ukraine, 02002

S. K hom en ko

Doctor of Agricultural Sciences, Senior Researcher, Head of Laboratory Spring Wheat Breeding laboratory The V. M. Remeslo Myronivka Institute of Wheat of National Academy of Agrarian Sciences of Ukraine Tsentralna str., 68, Tsentralne village, Kyiv region, Ukraine, 08853

V. Zorunko

$\mathrm{PhD}$, Associate Professor

Department of Plant Protection, Genetics and Breeding

Odessa State Agricultural Experiment Station

National Academy of Agrarian Sciences

Maiakskaia doroha, 24, Khlebodarske, Odessa region, Ukraine, 67667

O. B a la ba k

$\mathrm{PhD}$, Senior Scientist

Department of Genetics, Selection and Reproductive Biology of Plants

The National Dendrological Park "Sofiyivka" National Academy of Sciences of Ukraine Kievska str., 12A, Uman, Ukraine, 20300

V. Moskalets

Doctor of Agricultural Sciences, Senior Researcher**

T. Moskalets

Doctor of Biological Sciences, Associate Professor**

*Department of Technology of Storage and Processing of Grain Uman National University of Horticulture, Instytutska str., 1, Uman, Ukraine, 20305

**Selection and Technological Department Institute of Horticulture of the National Academy of Agrarian Sciences Sadova str., 23, Novosilky, Kyiv region, Ukraine, 03027

\section{Introduction}

Today, the production of cereals and wholemeal flour from common wheat and spelt has gradually decreased. This is the market reaction to the dynamics of population decline. The
Copyright (ङ 2020, N. Osokina, V. Liubych, V. Novikov, I. Leshchenko, V. Petrenko, S. Khomenko, V. Zorunko, O. Balabak, V. Moskalets, T. Moskalets This is an open access article under the CC BY license (http://creativecommons.org/licenses/by/4.0) driver of the development of the cereal industry in Ukraine can be entering the EU market of healthy food (wholegrain, organic farming, gluten-free dietary products).

The popularity of a particular type of cereal varies according to awareness of its usefulness and purchasing power 
of the population. An important prerequisite for stable market demand is the culinary quality of food. Currently, the main consumer trends are fast and instant cereals. The range of these cereals is constantly growing. At the same time, the market for food products grown by organic farming and gluten-free products is developing.

Emmer wheat (Triticum dicoccum (Schrank) Schuebl) is a type of film wheat. This species is thought to have originated from the wild Middle Eastern wheat Triticum dicoccoides Schweinf (wild wheat). Representatives of emmer wheat are characterized by endurance to excessive moisture and drought, cold resistance. In addition, they are tolerant of many fungal diseases, undemanding in soil fertility. The resistance of emmer wheat to powdery mildew and brown rust in organic farming was revealed. Grains in the ears are protected from pests and adverse external influences by a dense coverage with flower and spikelet scales. Given these advantages, emmer wheat is widely used in organic farming [1-3].

The biochemical properties of emmer wheat grain vary widely. The similarity of chemical composition and technological parameters with durum wheat is noted. The content of the main grain components is as follows: protein from 12.7 to $25.7 \%$; starch from 50.0 to 66.2 ; lipids from 0.9 to 4.9 ; fiber from 1.0 to $2.17 \%$ [4-9]. Emmer wheat grain is qualitatively different from common wheat in terms of nutritional value $[6,7,10,11]$. Lutein is more found in emmer wheat, which is expressed by a yellow tint of flour. Its significant content can be important for the prevention of visual disorders [12]. Emmer wheat grain contains more selenium, iron, manganese, zinc and copper than common wheat [11].

World production of emmer wheat is about $1 \%$ of total wheat production $[13,14]$. However, there is a steady increase in its production, particularly in the developed countries of Europe and North America. In the food industry, emmer wheat is used to make cereals and flour. Emmer wheat grain has high dietary properties. Due to slow absorption of starch, emmer wheat has a low glycemic index $[11,15]$. It also contains fewer allergens than common wheat and spelt. The products of emmer grain processing have high culinary quality.

It is known that the biochemical composition of the anatomical components of wheat grain differs. Most bioactive and phenolic substances are mainly concentrated in the outer layers (fruit, seed shells, aleurone layer) and germ. In traditional production of most types of cereals, their nutritional value in relation to grain is significantly reduced. Thus, the use of wholegrain products is considered the best solution to reduce the loss of bioactive compounds and increase the benefits for human health [16]. However, wholegrain cereals have worse culinary properties compared to traditional hulled cereals.

In response to the growing demand, the production of emmer wheat grain is increasing [17]. There is a need to find optimal methods to process it. However, due to low awareness of the cereal and milling properties of emmer wheat grain, processing plants are unable to effectively use the potential of this crop. Today, cereal production requires low initial investment. This is especially true for the latest heat treatment solutions. Therefore, there is a significant investment attractiveness due to low risks.

A known way to intensify grain processing technologies is the use of microwave irradiation. However, it is not used for wheat grain processing, and the level of research on this issue is insufficient. Therefore, the priority is given to:
- description of the mechanism of action of microwave irradiation on emmer wheat grain depending on moisture content;

- determination of dependences by means of complex analysis.

Determining patterns of influence of various parameters of water-heat treatment of emmer wheat grain will allow predicting the technical indicators of cereal production. In addition, it is necessary to optimize the yield of high-quality cereal. Research is therefore relevant.

\section{Literature review and problem statement}

Emmer wheat is a well-known crop in the world, as Triticum dicoccum is often used as a starting material in the interspecific and intergeneric hybridization of wheat. Examples of successful use of emmer wheat in breeding and subsequent hybridization with hulless wheat are given in $[18,19]$. It is shown that it is possible to obtain new varieties with characteristic properties of emmer wheat, in particular unpretentiousness to biotic, edaphic, climatic and other factors. At the same time, excellent cereal qualities of the grain are preserved. Nowadays, emmer wheat is gaining popularity in food production. Emmer wheat flour is used to improve common wheat flour, or to replace it completely [6]. Produced bread products have a yellow tint with a nutty aroma. According to the results of studies presented in [6], there is a difference between the technological properties of emmer wheat and common wheat, which necessitates the adaptation of classical baking technologies. When making bakery products from emmer wheat flour, a period of rest after kneading is needed for the flour polymers to swell. After that the dough acquires elasticity and firmness. Emmer wheat flour is suitable for products with low gluten requirements: cookies, cupcakes, waffles, biscuits [6].

Given the current features of the cereal market, in particular, the high demand for organic products, the processing of emmer wheat grain into cereals is a promising area. The work [14] shows the level of using emmer wheat grain in modern diets. It is noted that traditional emmer wheat products (whole and ground cereals) have a better taste, texture and aroma compared to similar products made of common wheat. Thus, semolina from emmer wheat grain has higher culinary properties compared to common wheat cereal and similar culinary score to durum wheat cereal [14].

Emmer wheat cereal boils quickly and does not form mucus during cooking. Porridge has a beautiful appearance, good crumbliness, pleasant smell and taste, increased biological and nutritional value. However, these studies concern the manufacture of ground and wholegrain cereals. In addition, the formation of culinary quality depending on the elements of processing technology is not sufficiently studied [14].

Water-heat treatment of wheat grain has a significant impact on the physical properties of grain. It significantly affects the range and nature of changes in the internal structure of processed raw materials. Traditionally, grain is first hulled. The obtained cereal product has a reduced biological value due to the reduction of water-soluble fractions of protein, fiber, lipids and minerals contained in the surface layers of grain.

The importance of water-heat treatment and effect on the yield of triticale flattened cereal are given in [20]. It is 
shown that an increase in hulling time significantly reduces the yield of cereal, but improves the culinary quality. Moistening of the grain had little effect on the yield and quality of the wholegrain cereal. The value of culinary quality together with the yield of wholegrain cereal increased with the use of larger grains due to the smaller number of hulls compared to small grains. From the results of [20], it follows that the formation of the culinary quality of flattened cereal depends on the residual content of hulls. At the same time, samples with a significant residual amount of fiber (hulls) had low culinary quality, which did not meet the competitiveness of the new finished product. The low suitability of triticale grain for the production of wholegrain cereals is evident as they have poor culinary quality.

The most similar in technological properties to emmer wheat grain is spelt. The cereal properties of spelt grain are sufficiently studied, in particular in [21]. A significant change in the cereal properties of spelt grain depending on the variety and line is proved. However, the disadvantage of [21] is the unresolved issues related to the influence of varietal features and endosperm content on the culinary properties of cereals, which is an important indicator of the competitiveness of a new product. The solution of the issue of the influence of cereal production parameters on the yield and culinary quality of the finished product (spelt wholegrain cereal) is given in [22]. It is shown that grain moistening has a significant but smaller effect on the yield of wholegrain cereal compared to hulling. The probability of the effect of softening time on the yield of wholegrain cereal was low. Most culinary indicators varied significantly depending on grain hulling time. The effect of water-heat treatment on the overall culinary score was insignificant.

The issue of hot conditioning of spelt (steaming and softening) is considered in [23]. It is shown that the yield of flattened cereals decreases with increasing grain hulling time. The reason is a decrease in the content of the hulls that held the endosperm particles. In [23], it is noted that with increasing grain hulling index, the cooking time of cereal decreases. The cooking time of flattened cereal does not depend on softening time, and steaming does not affect significantly. The parameters of water-heat treatment do not affect the culinary properties of porridge. Regardless of the time of grain steaming and softening, porridge with the lowest grain hulling coefficient had the worst consistency. The porridge had a tough consistency, crunched when chewed and formed lumps. Therefore, the spelt varieties studied in [23], similar to triticale grain, are not recommended for wholegrain products.

In [24], the results of studies related to the production of flattened cereals from emmer wheat grain are presented. It is shown that the use of grain processing in a microwave oven is technically possible. It is noted that a higher yield of flattened cereal is provided by the use of grain (without hulling) compared to the technology of producing wholegrain cereal. The time of grain processing in a microwave oven most affects the total yield of cereals and high-grade flattened cereal. Grain moistening does not significantly affect the yield of high-grade flattened cereal, regardless of the hulling or time of microwave irradiation. The culinary quality of high-grade flattened cereal porridge was not affected by moistening and irradiation. The consistency of porridge from flattened grain (without hulling) was quite tender, well chewed, with a weak crunch. The disadvantage of [24] is the low biological value of the studied raw materials, in particular low protein content $(11.7 \%)$ and powdery type of endosperm. It is inter- esting to study high-protein grain, because differences in the technological properties of new varieties of emmer wheat can cause quantitative and qualitative changes under the same production conditions of flattened cereals.

From the studies presented in [20,22], it follows that a product with high culinary quality can be obtained only by releasing triticale and spelt grain from the surface layers containing the major amount of dietary fiber. The work [12] focuses on the importance of dietary fiber for nutrition. One of the most affordable and cheap sources of dietary fiber is wholegrain products.

Differences in the technological properties of emmer wheat and common wheat, presented in [6], as well as the influence of varietal features on the yield and quality of cereals, determine the feasibility of studying the suitability of high-protein varieties of emmer wheat for the production of wholegrain products.

Along with the culinary quality of the finished product, an important indicator for the modern consumer is cooking time. Improving production technologies of food with low cooking time is a promising direction, as it has positive feedback from the end consumer and can be used in marketing strategies.

Reducing the cooking time of cereals and increasing their storage life are achieved using rigid methods of water-heat treatment, including hot conditioning.

Most grain processing plants use the method of grain steaming at excess pressure. The purpose of this process is to reduce the brittleness of the kernel, increase plasticity, which reduces the brittleness of cereal during flattening. During steaming, the grain is moistened and heated. Steam condenses on the surface of the kernel and is absorbed by the grains. Further penetration of moisture into the nucleus helps to increase the plasticity of the endosperm. As a result, the cereal yield increases and cooking time decreases [23]. The disadvantage of traditional hot conditioning methods is a significant increase in moisture content, which causes grain sticking. Before flattening, the moisture content should not exceed $23-25 \%$, and the final moisture content of flattened cereal should not exceed $14.0 \%$. The recommended moisture content of grain at all processing stages is achieved through drying, which is quite a costly operation.

An innovative method of water-heat treatment that significantly reduces the energy consumption of the process is infrared (micronization) and microwave irradiation.

A significant disadvantage of the micronization process is the resource-intensive process of preliminary moistening and softening of grain. When using infrared irradiation, it is necessary to increase the grain moisture content to $28.0-34.0 \%$.

Microwave irradiation has a number of advantages and is widely used in food production: heating or thawing products, drying pasta, cooking, etc. In grain processing, microwave irradiation is used for disinfection, drying and improving the technological properties of grain, but there are recommendations [25] regarding introducing microwave irradiation as heat treatment of grain.

In $[25,26]$, it is noted that in the food industry, magnetrons are commonly used as a microwave source. The operating irradiation frequency of magnetrons ranges from 915 to $2,450 \mathrm{MHz}$. In domestic use (microwave oven), the frequency of $2,450 \mathrm{MHz}$ is used. Therefore, microwaves are not ionizing in nature. Microwave irradiation does not have enough energy to cause chemical changes compared to radioactive irradiation, so the resulting products are safe to eat. 
Microwave irradiation causes oscillations of bound electric charges (dipoles) in the grain. This creates dielectric heating at the sites of water and lipids. The microwave electromagnetic field does not actually affect the chemical composition. The driving factor of processes in the grain is heat.

In [27-29], the results of studies of the effect of grain heating by the convective method and microwave irradiation are presented. It is shown that under the action of microwave irradiation there is comprehensive heating of the grain. Such heating causes an intense transition of water into a gaseous state. During this process, the grain size increases, and the internal structure of the grain becomes powdery. In the central parts of the grain, physicochemical transformations occur, in particular the breakdown of protein chains, dextrinization of starch. Concomitant processes are an increase in the content of water-soluble substances, nutritional value, digestibility of the finished product and reduction of the cooking time of cereals. In [30], the results of studies on the effect of buckwheat grain treatment in a microwave oven are given. It is shown that fungal spores are destroyed as a result of microwave irradiation. Products after treatment in a microwave oven increase their microbiological safety and shelf life.

An important aspect when choosing grain processing methods and modes is the preservation of functional properties. In [31], the effect of electromagnetic radiation on grain crops is given. It is shown that irradiation of wheat grain in a microwave oven does not significantly affect the content of useful nutrients. In [28, 32], the results of studies of changes in the biochemical composition and technological properties of common wheat grain are presented. It is shown that after microwave irradiation no significant changes in the amount of protein were detected. However, partial denaturation of gluten occurs. The essence of changes in the qualitative composition of proteins is given more thoroughly in the study of buckwheat grain treatment in a microwave oven [30]. It is shown that under the action of microwave irradiation, partial denaturation of protein occurs. At the same time, there is an increase in the content of certain free amino acids, namely lysine, isoleucine, methionine, phenylalanine, threonine. However, the nitrogen content remained the same, which indicates the absence of protein destruction. With a significant increase in temperature, after microwave irradiation, thermal denaturation of glutenin proteins occurs in the grain [32]. One manifestation is a decrease in the cross-reactivity of gliadin with the R5 antibody. The processes occurring in the grain under the action of microwave irradiation are studied insufficiently. However, it can be argued that processing grain in a microwave oven does not significantly affect the biological value of the product. It is advisable to use microwave radiation to obtain dietary products for groups of people with gluten sensitivity.

The rate and degree of heating significantly depend on the time and power of microwave irradiation. It is known [30] that the growth rate of the grain temperature is greater at a higher generated power of the magnetron. At the same magnetron power - at lower moisture content of grain. This is because heating grain with higher moisture content requires more energy. On the other hand, higher moisture content of grain leads to the formation of more steam and more intense biochemical processes. After evaporation of free water, the temperature of the product rises rapidly, creating a risk of fire.

The use of microwave irradiation in the manufacture of cereals is little covered in the literature. Most often, micro- wave irradiation is used to produce "puffed" cereals from corn and buckwheat grains. The effect on the yield and quality of flattened cereals from emmer wheat grain is not found in the literature. Most studies concern the technological and rheological properties of flour obtained from irradiated grain $[31,32]$. Some works are devoted to changes in the biochemical composition and safety of consumption [29,30]. These properties do not describe the effect on the yield and quality of flattened cereals.

In market conditions, the quantitative yield of cereal loses its priority. The competitiveness of cereal depends on quality and price. These factors regulate consumer demand. Therefore, it is reasonable to study the relationship between different grain treatment times, yield and culinary characteristics of the finished product.

The cost of cereal can be reduced by increasing the yield, but to ensure competitiveness cereals should be produced under optimal modes, which combine three factors: the yield, culinary quality and biological value of cereal.

In $[25,28,32]$, which studied microwave irradiation of cereal grains, no effective method was proposed in the production of flattened cereals, and the issue of processing emmer wheat into wholegrain flattened cereals using microwave irradiation was not studied. Mechanisms need to be found to change the yield and culinary quality of cereal depending on irradiation time and moistening of emmer wheat grain, which is an interesting question from a theoretical and practical point of view. Determining patterns and mechanisms will intensify cereal production. This is a prerequisite for the transfer of technological solutions and their application in the existing cereal plants of different capacities.

\section{The aim and objectives of the study}

The aim of the study was to determine optimal modes of irradiation and moistening of emmer wheat grain in terms of yield and culinary quality of the finished product. This will make it possible to produce flattened emmer wheat cereal with high culinary quality. Quality indicators of cereal will meet the requirements of DSTU 1055: 2006. "Quick-cooking cereals. Specifications" and ISO 22000: 2005 "Food safety management system implemented in the production". The results of the study will be valuable for low-capacity enterprises.

To achieve the aim, the following objectives were set:

- to determine the effect of microwave irradiation time and moistening of emmer wheat grain on the yield of cereal;

- to determine the possibility of microwave irradiation of grain in the production of flattened cereals;

- to investigate the culinary quality of cereal depending on production parameters;

- to substantiate rational modes of processing emmer wheat grain into cereal.

\section{Methods of studying the influence of production} parameters on the yield and quality of flattened cereal

\section{1. Raw materials for studying the efficiency of mi-} crowave treatment in cereal production

Emmer wheat grain of the Golikovska variety (the first emmer wheat variety in Ukraine) was used for the study. Raw materials were grown in the right-bank Forest-Steppe (Educational and Production Department of the Uman National Uni- 
versity of Horticulture (Uman, Ukraine)). The initial moisture content of grain was $12.0 \%$; protein content was $14.3 \%$.

\section{2. Methods for studying the effect of microwave} treatment

The study was conducted in the laboratory of the Department of Grain Storage and Processing Technology of the Uman National University of Horticulture (Uman, Ukraine).

The production of flattened cereal from wheat grain was modeled in the laboratory (Fig. 1) in accordance with the "Rules of organization and conduct of technological processes at cereal plants" [33].

Water-heat treatment of grain included moistening and microwave irradiation. The amount of water required to moisten the grain was calculated in accordance with the recommendations of the "Rules of organization and conduct of technological processes at cereal plants" [33].

Microwave irradiation of grain was performed in a RAINFORD RMW-301 DGC/S microwave oven (China), rated power $1,000 \mathrm{~W}$, microwave frequency $2,450 \mathrm{MHz}$. This device is not specialized laboratory equipment. However, it should be noted that many researchers also use household microwave ovens. This creates some errors in research, due to the imperfect distribution of electromagnetic radiation, because they were not designed for this purpose [25]. However, they provide an opportunity to study the necessary general aspects of the effect of microwave radiation on grain.
The mass of the sample was $100 \mathrm{~g}$. The sample was evenly distributed on a round plate. After microwave irradiation, the raw material was flattened without allowing the grain to cool. The reduction of the distance between the rolls of the flattening machine causes an increase in the production of broken cereals.

The grain was treated according to factorial design ( Table 1). It contained all possible combinations of factors, repeated at each level the same number of times.

Table 1

Steps and levels of variation of the experiment determining the effect of production parameters on its efficiency

\begin{tabular}{|c|c|c|}
\hline Level & Irradiation time, $\mathrm{s}$ & $\begin{array}{c}\text { Moisture con- } \\
\text { tent, } \%\end{array}$ \\
\hline Minimum & 20 & 12.0 \\
\hline Zero & 100 & 13.0 \\
\hline Maximum & 180 & 14.0 \\
\hline Step & 80 & 1.0 \\
\hline
\end{tabular}

The factor of softening time was not studied. According to the recommendations for wheat grain processing [33], the mode was chosen for all options, which included a softening time of 30 minutes.

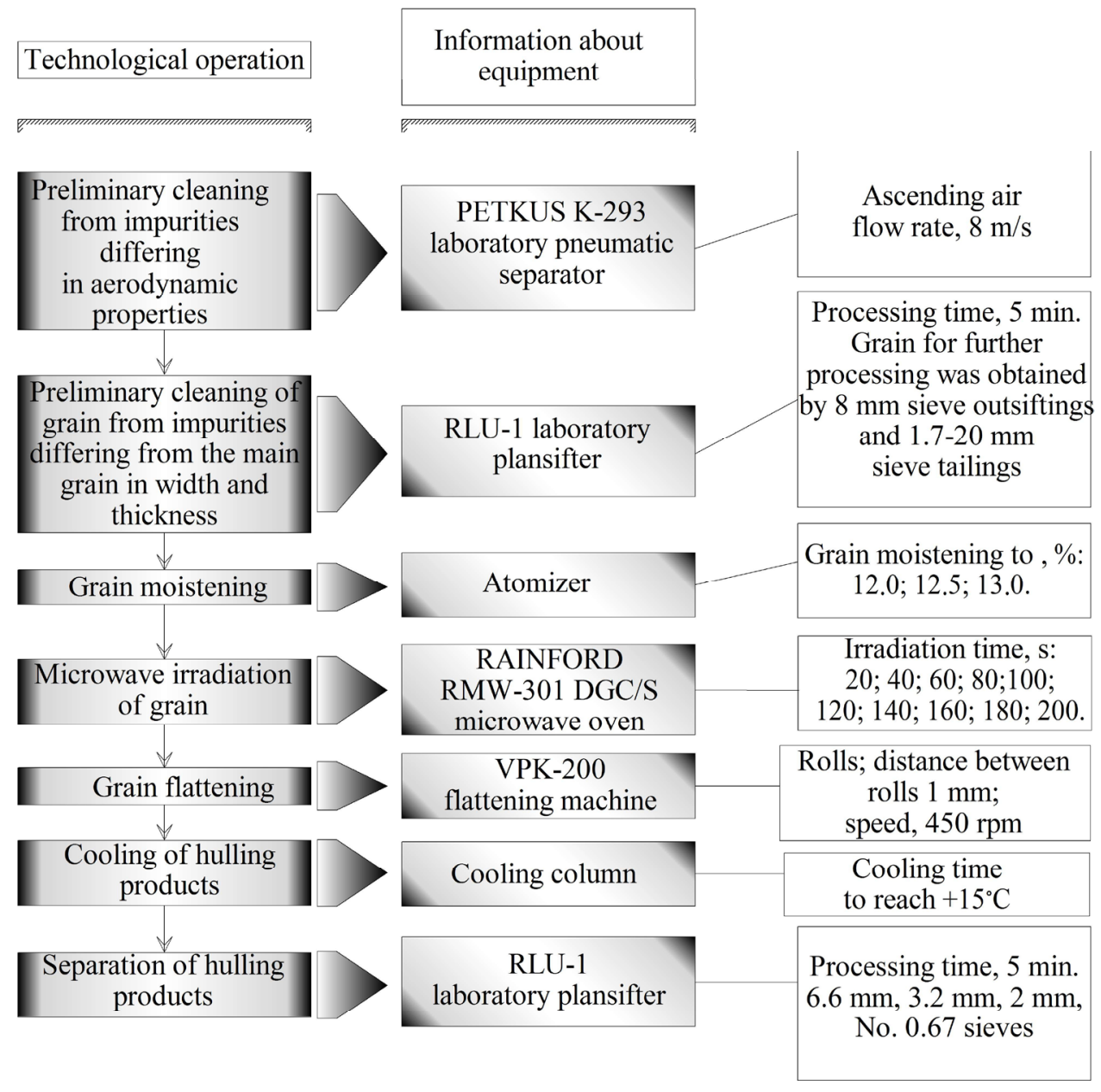

Fig. 1. Schematic diagram of production of flattened cereal in the laboratory 
After cooling, the cereal mixture was separated on an RLU-1 laboratory plansifter. 5 fractions were obtained using three sieves with round holes $(6.5 ; 3.2 ; 2.0 \mathrm{~mm})$ and a wire sieve (No. 0.67). Considering the geometric dimensions and fragility of the grains during flattening, the obtained fractions had flakes with different widths, which varied among the working dimensions of the respective sieves. For example, the width of the flakes obtained by the 3.2 sieve outsiftings and 2.0 sieve tailings ranged from 2.0 to $3.2 \mathrm{~mm}$. Detailed characteristics of the fractions are given in Table 2.

Culinary evaluation was performed according to the patent No. 104152 "Method of culinary evaluation of cereals from triticale and wheat grain".

Table 2

Characteristics of different fractions of flattened cereal

\begin{tabular}{|c|c|c|}
\hline Fraction number & Production conditions & $\begin{array}{c}\text { Flake diam- } \\
\text { eter, } \mathrm{mm}\end{array}$ \\
\hline stuck grains & $6.5 \mathrm{~mm}$ sieve tailings & $<6.5$ \\
\hline $\begin{array}{c}\text { high-grade flattened } \\
\text { cereal }\end{array}$ & $\begin{array}{c}6.5 \mathrm{~mm} \text { sieve outsiftings } \\
3.2 \mathrm{~mm} \text { sieve tailings }\end{array}$ & $6.5-3.2$ \\
\hline $\begin{array}{c}\text { first-grade flattened } \\
\text { cereal }\end{array}$ & $\begin{array}{c}3.2 \mathrm{~mm} \text { sieve outsiftings } \\
2.0 \mathrm{~mm} \text { sieve tailings }\end{array}$ & $3.2-2.0$ \\
\hline chop (cereal) & $\begin{array}{c}2.0 \text { sieve outsiftings } \\
\text { No. } 0.67 \text { sieve tailings }\end{array}$ & $2.0-0.67$ \\
\hline feed meal & No. 0.67 sieve outsiftings & $>$ \\
\hline
\end{tabular}

\section{3. Statistical processing of experimental data}

The study was performed in three repetitions that were randomized over time. The results were processed using Microsoft Excel 2010 (Microsoft, USA) and Statistica 12 (Dell, USA) in accordance with the guidelines $[34,35]$. The degree of influence of factors was determined according to Partial eta-squared $\left(\Pi^{2}\right)$. The degree of influence was estimated by the following distribution: 0.01-0.06 - low; 0.06-0.14 - average; more than 0.14 - high influence. A Pareto diagram was used to determine the proportion of factor influence.

\section{Results of studying the effect of moistening and irradiation of grain on the yield and quality of flattened cereals}

\section{1. Yield of flattened wholegrain cereal}

Samples of yield data for all fractions of cereals and feed meal obtained without moistening and after moistening for different times of microwave processing are summarized in Table 3.

The variation of the sample data on the yield of the three fractions of cereals obtained after moistening was smaller compared to those obtained without it. This indicates a smaller deviation of the values of the corresponding parameter from the average value of the sample. The variation of the sample data on the yield of cereals and related products (chop and meal) was significant (Coef.Var.>10). The variation of the samples of the total cereal yield was insignificant, which indicates a low probability of the effect of microwave processing parameters of the samples on the corresponding indicator.
Table 3

The relationship between the total cereal yield $(p<0.05)$, the yield of high-grade flattened cereal $(p<0.05)$, water-heat treatment parameters $(p<0.05)$ and microwave irradiation is determined (Fig. 2).
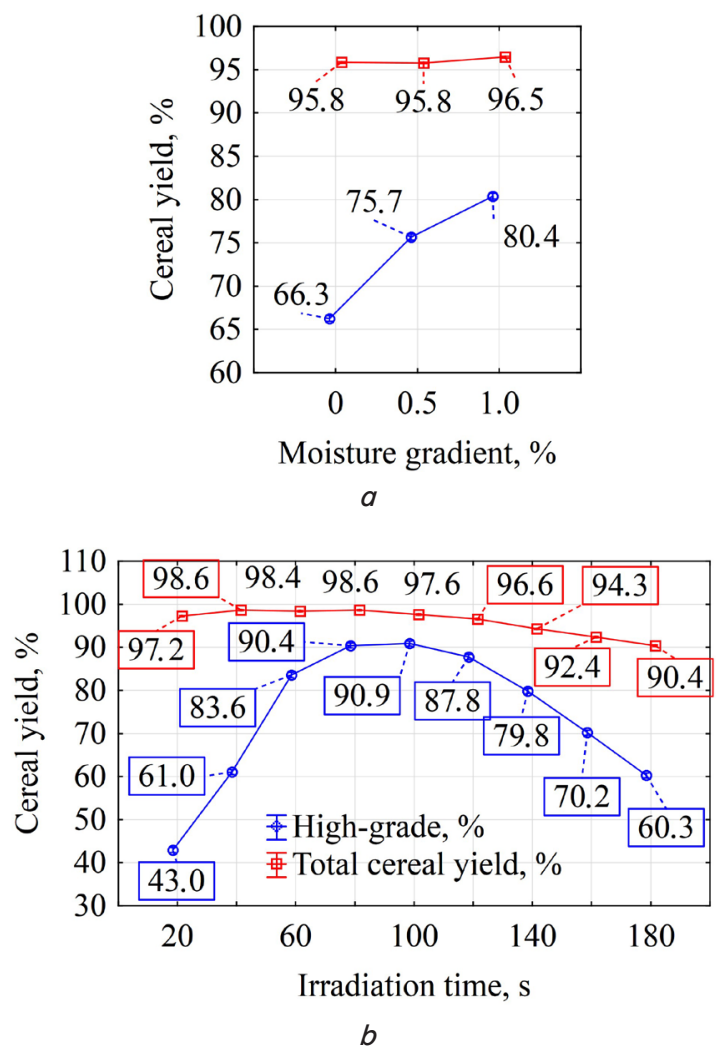

Fig. 2. Effect of microwave irradiation and moistening of grain on the total yield of cereals and high-grade cereal: $a$ - effect of moistening, $\% ; b-$ effect of microwave irradiation time, $\mathrm{s}$

The total yield of cereals did not change significantly with different moistening gradients. At different times of microwave irradiation, this figure varied from 90.4 to $98.6 \%$. The yield of high-grade flattened cereal changed significantly with moistening. The average value of this indicator increased compared to dry grain by $18 \%$ with a moisture gradient of $1.0 \%$. Microwave irradiation time had a greater effect on the yield of high-grade cereal. For a duration of 20 to $100 \mathrm{~s}$, the yield of this cereal increased to $90.6 \%$. After increasing the irradiation time (180 s), the yield decreased by 1.5 times. 
5. 2. Substantiation of the usefulness of microwave irradiation during cereal production

Grain moistening is gradual due to anisotropy. The penetration of moisture into the inner layers of the grain depends on many factors, including moisture gradient, softening time, temperature of water and the environment [20]. In addition, the characteristics of the surface layers of the grain (hulls and aleurone layer) have a significant impact on the course of the moistening process.

The greatest effect on the yield of cereal was due to the time of microwave irradiation of grain (Fig. 3).

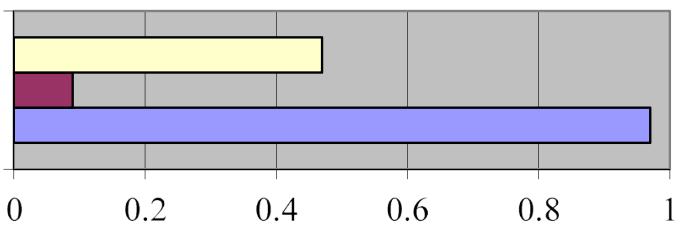

$\square$ Combined effect of factors 1 and 2

$\square$ Moisture gradient (Factor 2)

$\square$ Microwave irradiation (Factor 1)

Partial eta-squared

$a$

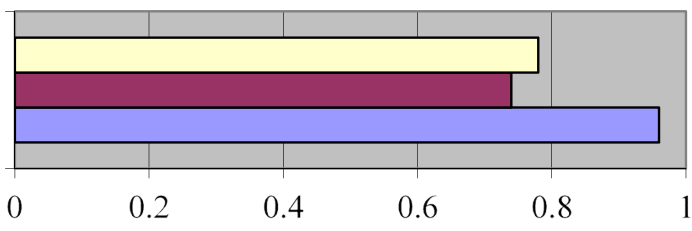

Partial eta-squared $b$

Fig. 3. Degree of influence of water-heat treatment parameters of grain on the yield of cereal: $a$ - total yield; $b-$ high-grade cereal yield (Factor 2)

$\square$ Microwave irradiation (Factor 1) ed by grain hulling [20,22]. Varietal characteristics of grain have a somewhat smaller effect. Grain moistening does not significantly affect the quality of porridge [24].

It is known that grain hulls degrade the culinary quality of the finished product in terms of consistency during chewng and color and also significantly increase the time of porthe overall culinary quality of the cereal did not change depending on the processing elements.

The smell of the porridge was weak (5.7 points), and the consistency during chewing was tough (5 points). Despite this, the overall culinary quality of the porridge was high (7.3 points). After cooking, swollen grains retained their shape. This positively affected the external attractiveness of the porridge. With a similar culinary quality of the porridge, we obtained flattened cereal from emmer wheat grain with a hulling index of $3.2-6.9 \%$ [36]. However, the steaming method was then used as heat treatment. Obviously, in the production of flattened cereals by microwave irradiation, grain hulls soften. This can be explained by the greater weakening of the linkage of high-polymer macromolecules.

The overall culinary quality of the first-grade cereal did not differ significantly from the high-grade one. However, the external attractiveness of this porridge is lower because the grains somewhat lost their shape after cooking. This is due to the fact that they have an irregular shape with a torn periphery.

The cooking time does not directly af-

The degree of influence of grain moistening varied depending on the considered indicator. For the total yield of cereal, grain moistening was not essential, which makes it possible to exclude the corresponding operation from the technological process. In the context of the high-grade cereal yield, grain moistening has a significant effect (the level of influence is 7 times higher than the effect of grain moistening).

Additional costs for selecting high-grade flattened emmer wheat cereal can be offset by the cost of the finished product of high culinary quality and stable demand for it. Therefore, microwave irradiation of grain in the production of flattened cereals is possible at low-capacity enterprises. The use of microwave radiation at high-capacity plants requires additional research and industrial testing.

\section{3. Culinary quality of flattened cereal}

It is known [20] that the culinary properties of the finished product are crucial for the end consumer. Culinary properties (taste, color, consistency during chewing) are significantly affect-

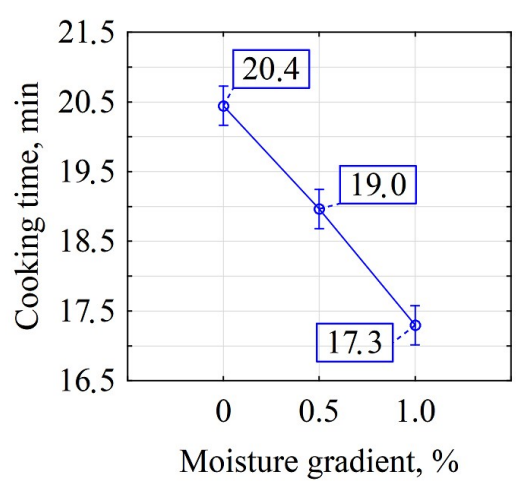

$a$ fect the overall culinary quality. Information on the reduction of cooking time should be used as a positive factor for marketing purposes. Water-heat treatment of grain had a significant impact on the cooking time of high-grade cereal (Fig. 4, $a$ ). Thus, moistening by $1 \%$ caused a decrease in cooking time by $7 \%$ compared to dry grain. Microwave irradiation of grain had a greater effect on the cooking time (Fig. 4, $b$ ).

For $20 \mathrm{~s}$ of microwave irradiation, the cooking time was $19.1 \mathrm{~min}$. The increase in treatment time to $180 \mathrm{~s}$ reduced the cooking time to $15.9 \mathrm{~min}$ or by $17 \%$. are significantly affect-

Fig. 4. Effect of grain moistening and microwave irradiation on the cooking time of high-grade

grain: $a$ - effect of moistening; $b$ - effect of microwave irradiation

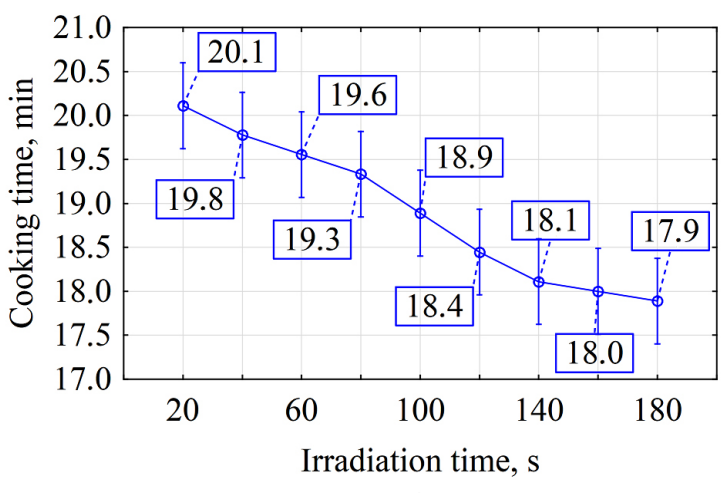

$$
b
$$




\section{4. Rational modes of processing emmer wheat grain into cereal}

To determine the optimal grain processing modes, a desirability function is constructed. The conditions of optimization can be cereal yield and culinary quality. Thus, in studies, the culinary quality of porridge did not change under different processing modes. Therefore, it is advisable to choose the production modes that provide the highest yield of high-grade cereal. Moistening emmer wheat grain by $0.5-1.0 \%$ before microwave treatment has the greatest effect on the cereal yield.

The optimal time of grain irradiation is from 80 to $100 \mathrm{~s}$. During this time, the largest amount of high-grade cereal was obtained, $91.3-92.3 \%$.

\section{Discussion of the results of the study of processing emmer wheat grain into flattened cereal}

An increase in the time of microwave irradiation of grain (up to $100 \mathrm{~s}$ ) at different moisture contents contributed to a significant increase in high-grade cereal (Fig. 2, $b$ ). This is due to the effect of microwave irradiation on biochemical processes in the grain. During irradiation, the grain was heated, accompanied by transformations in protein and starch complexes. The obtained trends are similar to the results given in $[28,32]$, which determines the similarity of the response to irradiation of emmer and common wheat. Proteins are denatured into simpler components. Partial dextrinization of starch takes place. At the same time, these complexes acquire adhesive properties. However, with prolonged microwave irradiation (over $100 \mathrm{~s}$ ), the grain components are exposed to high thermal effects. Prolonged high-temperature treatment of grain is accompanied by deep irreversible processes. Proteins and starch lose their adhesion ability. As a result, the grains do not stick together after deformation between the rolls of the flattening machine. The yield of high-grade cereal decreases, while the yield of first-grade cereal and related products (chop, meal), on the contrary, grows.

Grain moistening improved the yield of high-grade cereal by $18 \%$ (Fig. 2,a). With a moisture content of $0.5 \%$, a rapid increase in the total yield of cereal was observed (66.3-75.7\%). An increase in the moisture index to $1.0 \%$ contributes to a further increase in cereal yield, characterized by lower intensity. Therefore, excessive moistening of the grain is impractical. The positive effect of grain moistening is explained by the formation of a film on the grain surface, which inhibits the rapid evaporation of moisture from the grain. As a result, biochemical processes in the grain are accelerated.

The results of the studies show that processing grain in the microwave field has a positive effect on the yield of cereal. There is equipment for irradiation with continuous operation. This is important because the use of equipment with periodic operation is less efficient and requires a significant increase in fixed assets (operational hoppers for grain softening). After heat loss, the endosperm of the irradiated grain is fixed due to the gelatinization of proteins with starch.

Traditional methods of water-heat treatment in the production of flattened cereal [33] have significant disadvantages: frequency (the need for tempering); dependence on environmental conditions (decrease in temperature requires an increase in softening time, or additional heating of grain and water); the need for drying. Microwave irradiation can be an alternative to the traditional steaming process, as it eliminates most of its disadvantages.
Microwave processing of grain is accompanied by positive changes in the culinary quality of the finished product, in particular, significantly improves its smell. After 100-120 s of irradiation, the cereal acquired a pleasant smell with a nutty aroma. This can be explained by the formation of melanoid compounds, as the grain temperature exceeded $100{ }^{\circ} \mathrm{C}$.

The culinary quality of the obtained product was satisfactory (at least 5.0 points), which determines the feasibility of using emmer wheat grain to produce wholegrain cereal, which is impossible in the processing of spelt and triticale wheat [20,22].

Raising consumer awareness of nutrition issues will stimulate the market for products with high biological quality [37]. Wholegrain emmer wheat cereal is highly competitive due to increased biological value, in particular, increased protein content, including a significant proportion of water- and salt-soluble fractions [24]. In addition, emmer wheat is tolerant to certain diseases and adverse climatic conditions [38]. This creates prerequisites for growing this crop through organic farming. The hulls of common wheat grains acquire considerable strength, giving a very hard consistency when chewed with a strong crunch [24]. In contrast, the hulls of emmer wheat grain are easily chewed with a weak crunch, which meets the minimum requirements for the culinary quality of the finished product.

The recommended modes can be applied to Golikovska emmer wheat grain or others that have similar technological characteristics. Processing emmer wheat grain with other technological properties requires a separate study. It should be noted that the developed recommendations have limitations, namely the developed modes provide for the use of emmer wheat grain with a high protein content $(>14 \%)$. The use of grains with lower protein content will lead to lower yields of high-grade cereal with lower culinary properties [24].

The issue of using microwave irradiation as heat treatment of grain is relevant and has practical significance for the modern grain processing industry. The identified effects of grain irradiation before flattening indicate the prospects for implementing the proposed treatment methods in production.

The shortcomings of the studies include the lack of technical and economic indicators of cereal production using microwave irradiation. It is advisable to further study the energy intensity of the microwave irradiation process and compare it with traditional hot conditioning methods for existing enterprises. In addition, a detailed study of the reduction of investment risks as a result of integrating the microwave irradiation process into the projects of new cereal plants of various capacities is required.

The studies were conducted using the moistening and softening guidelines for common and durum wheat grain [33]. It is advisable to further study the extended range of grain moisture content before microwave irradiation and its effect on the yield and quality of the finished product.

The safety indicators of the finished product need to be clarified, in particular, microbiological changes in emmer wheat grain of different grades and the quality of the finished product as a result of microwave irradiation before flattening.

\section{Conclusions}

1. The yield of high-grade flattened cereal was most affected by irradiation time. The effect of moistening on the yield of this cereal was smaller, but significant. Moistening 
of emmer wheat grain by $1.0 \%$ allows increasing the yield of the high-grade flattened cereal from 89.6 to $92.3 \%$. The time of irradiation is reduced from 100 to $80 \mathrm{~s}$.

2. The effect of moistening and time of electromagnetic irradiation of grain on the yield and quality of flattened wholegrain cereal is determined. Moistening did not significantly affect the overall yield of cereal. An increase in the time of microwave irradiation (more than 100-120s) caused an increase in the yield of flour, but the yield of cereals decreased.

3. The parameters of water-heat treatment of grain do not affect the culinary quality of the finished product. The cooking time of high-grade cereal decreased due to moistening and irradiation of grain. With the lowest irradiation of grain $(20 \mathrm{~s})$, the cooking time of high-grade cereal was 19.1 minutes, and after long-term (180 s) - 15.9 minutes.

4. In the production of flattened wholegrain cereal from emmer wheat, it is possible to use unhulled grain. It is optimal to moisten the grain by $0.5-1.0 \%$ with the irradiation time of $80-100 \mathrm{~s}$. The use of such processing parameters provides a yield of $91.7-92.3 \%$ of high-grade flattened cereal with a culinary score of 7.3 points, which is a high result.

\section{References}

1. Caballerol, M. L. M., Alvarez, J. B. (2012). Collection and characterisation of populations of spelt and emmer in Asturias (Spain). Czech Journal of Genetics and Plant Breeding, 41 (Special Issue), 175-178. doi: http://doi.org/10.17221/6162-cjgpb

2. Konvalina, P., Capouchová, I., Stehno, Z., Moudrý, J. (2010). Agronomic characteristics of the spring forms of the wheat landraces (einkorn, emmer, spelt, intermediate bread wheat) grown in organic farming. Journal of Agrobiology, 27 (1), 9-17. doi: http://doi.org/ 10.2478/s10146-009-0002-3

3. Laghetti, G., Fiorentino, G., Hammer, K., Pignone, D. (2009). On the trail of the last autochthonous Italian einkorn (Triticum monococcum L.) and emmer (Triticum dicoccon Schrank) populations: a mission impossible? Genetic Resources and Crop Evolution, 56 (8), 1163-1170. doi: http://doi.org/10.1007/s10722-009-9439-x

4. Mitrofanova, O. P., Khakimova, A. G. (2016). New genetic resources in wheat breeding for an increased grain protein content. Vavilov Journal of Genetics and Breeding, 20 (4), 545-554. doi: http://doi.org/10.18699/vj16.177

5. Desheva, G. N., Kyosev, B. N., Stoyanova, S. D., Sabeva, M. D. (2016). Grain quality of emmer germplasm (Triticum dicoccon) from the National Collection of Bulgaria. Phytologia balcanica, 22 (2), 223-232.

6. Lacko-Bartošová, M., Čurná, V., Lacko-Bartošová, L. (2015). Emmer - ancient wheat suitable for ecological farming. Research Journal of Agricultural Science, 47 (1), 3-10.

7. Stehno, Z., Paulíčková, I., Bradová, J., Konvalina, P., Capouchová, I., Mašková, E. et. al. (2011). Evaluation of emmer wheat genetic resources aimed at dietary food production. Journal of Life Sciences, 5, 207-212.

8. Lacko-Bartošová, M., Čurná, V. (2015). Nutritional characteristics of emmer wheat varieties. Journal of Microbiology, Biotechnology and Food Sciences, 4 (Special issue 3), 95-98. doi: http://doi.org/10.15414/jmbfs.2015.4.special3.95-98

9. Ruzhitska, O. M., Borysova, O. V. (2018). Seed productivity and biochemical composition of spelt winter wheat and emmer wheat under south steppe zone conditions. Plant physiology and genetics, 50 (2), 161-169.

10. Chugunova, O. V., Kryukova, E. V. (2015). Agronomic properties of spelt as unconventional raw materials for production of flour confectionery products. Science Bulletin, 5 (3), 90-100. doi: http://doi.org/10.17117/nv.2015.03.090

11. Čurná, V., Lacko-Bartošová, M. (2017). Chemical composition and nutritional value of emmer wheat (Triticum dicoccon Schrank): a review. Journal of Central European Agriculture, 18 (1), 117-134. doi: http://doi.org/10.5513/jcea01/18.1.1871

12. Shewry, P. R., Hey, S. J. (2015). The contribution of wheat to human diet and health. Food and Energy Security, 4 (3), 178-202. doi: http://doi.org/10.1002/fes3.64

13. Zaharieva, M., Ayana, N. G., Hakimi, A. A., Misra, S. C., Monneveux, P. (2010). Cultivated emmer wheat (Triticum dicoccon Schrank), an old crop with promising future: a review. Genetic Resources and Crop Evolution, 57 (6), 937-962. doi: http://doi.org/ 10.1007/s10722-010-9572-6

14. Dhanavath, S., Prasada Rao, U. J. S. (2017). Nutritional and Nutraceutical Properties ofTriticum dicoccumWheat and Its Health Benefits: An Overview. Journal of Food Science, 82 (10), 2243-2250. doi: http://doi.org/10.1111/1750-3841.13844

15. Vecherska, L. A., Relina, L. I., Golik, O. V. (2018). Emmer: benefits, drawbacks and prospects. Bulletin of Uman National University of Horticulture, 2, 10-16. doi: http://doi.org/10.31395/2310-0478-2018-21-10-16

16. Ragaee, S., Seetharaman, K., Abdel-Aal, E.-S. M. (2014). The Impact of Milling and Thermal Processing on Phenolic Compounds in Cereal Grains. Critical Reviews in Food Science and Nutrition, 54 (7), 837-849. doi: http://doi.org/10.1080/10408398.2011.610906

17. Kirilenko, N. A., Ruzhitska, O. M., Borisova, O. V. (2016). Anatomical and morphological features of stems and leaves of filmy types of triticum spelta L. and T. dicoccum (Schrank) Schuebl. Odesa National University Herald. Biology, 21 (1 (38)), 50-61. doi: http://doi.org/10.18524/2077-1746.2016.1(38).68615

18. Konvalina, P., Capouchová, I., Stehno, Z., Moudrý, J., Moudrý, J. Jr., Márton, L. (2011). Variation for carbon isotope ratio in a set of emmer (Triticum dicoccum Schrank) and bread wheat (Triticum aestivum L.) accessions. African Journal of Biotechnology, 10 (21), 4450-4456.

19. Babenko, L. M., Rozhkov, R. V., Pariy, Y. F., Pariy, M. F., Kosakisvska, I. V., Vodka, M. V. (2017). Triticum dicoccum (Schrank) Schuebl.: origin, biological characteristics and perspectives of use in breeding and agriculture. Vìsnik Harkivs'kogo Nacìnal'nogo Agrarnogo Unìversitetu. Seriâ Bìologiâ, 2 (41), 92-102. doi: http://doi.org/10.35550/vbio2017.02.092 
20. Liubych, V., Novikov, V., Zheliezna, V., Prykhodko, V., Petrenko, V., Khomenko, S. et. al. (2020). Improving the process of hydrothermal treatment and dehulling of different triticale grain fractions in the production of groats. Eastern-European Journal of Enterprise Technologies, 3 (11 (105)), 55-65. doi: http://doi.org/10.15587/1729-4061.2020.203737

21. Gospodarenko, G. M., Martyniuk, A. T., Lyubich, V. V., Polyanetska, I. O. (2017). Cereal properties of grain of different grades and lines of spelled wheat. Bulletin of Dnipropetrovsk State Agrarian and Economic University, 1 (43), 12-16.

22. Liubych, V., Novikov, V., Polianetska, I., Usyk, S., Petrenko, V., Khomenko, S. et. al. (2019). Improvement of the process of hydrothermal treatment and peeling of spelt wheat grain during cereal production. Eastern-European Journal of Enterprise Technologies, 3 (11 (99)), 40-51. doi: http://doi.org/10.15587/1729-4061.2019.170297

23. Hospodarenko, G. M., Poltoretskyi, S. P., Liubych, V. V., Zheliezna, V. V. (2018). Improvement of the parcooking mode for the rolled groats production of spelt wheat. Collected Works of Uman National University of Horticulture, 93 (1), 8-22. doi: http:// doi.org/10.31395/2415-8240-2018-93-1-8-22

24. Osokina, N. M., Liubych, V. V., Novikov, V. V., Leshchenko, I. A. (2020). Yield of spelt wheat rolled grits depending on exposure time to microwave EMF (electromagnetic field of high-frequency current) and water treatment. Collected Works of Uman National University of Horticulture, 1 (96), 52-71. doi: http://doi.org/10.31395/2415-8240-2020-96-1-52-71

25. Kil, Y., Joy, C., Silva Clerici, M. T. P. (2011). The Use of Microwave Radiation Energy to Process Cereal, Root and Tuber-based Products. Advances in Induction and Microwave Heating of Mineral and Organic Materials, 531-552. doi: http://doi.org/10.5772/14177

26. Lucas, J. (2018). Microwave Radiation. CIRP Encyclopedia of Production Engineering, 1-6. doi: http://doi.org/10.1007/ 978-3-642-35950-7 6488-4

27. Neill, G., Al-Muhtaseb, A. H., Magee, T. R. A. (2012). Optimisation of time/temperature treatment, for heat treated soft wheat flour. Journal of Food Engineering, 113 (3), 422-426. doi: http://doi.org/10.1016/j.jfoodeng.2012.06.019

28. Lamacchia, C., Landriscina, L., D'Agnello, P. (2016). Changes in wheat kernel proteins induced by microwave treatment. Food Chemistry, 197, 634-640. doi: http://doi.org/10.1016/j.foodchem.2015.11.016

29. Qu, C., Wang, H., Liu, S., Wang, F., Liu, C. (2017). Effects of microwave heating of wheat on its functional properties and accelerated storage. Journal of Food Science and Technology, 54 (11), 3699-3706. doi: http://doi.org/10.1007/s13197-017-2834-y

30. Furmanova, Y. P. (2012). Buckwheat Product Technology. Kyiv, 22.

31. Mazima, J. K., Johnson, A., Manasseh, E., Kaijage, S. (2018). An overview of electromagnetic radiation in grain crops. Food Science and Technology: An International Journal, 1 (1), 21-32.

32. Diraman, H. (2010). Effect of Microwaves on Technological and Rheological Properties of Suni-Bug (Eurygaster spp) Damaged and Undamaged Wheat Flour. Food Science and Technology Research, 16 (4), 313-318. doi: http://doi.org/10.3136/fstr.16.313

33. Kroshko, H. D., Levchenko, V. I., Nazarenko, L. N. ta in. (1998). Pravyla orhanizatsii i vedennia tekhnolohichnoho protsesu na krupianykh zavodakh. Kyiv: Viola, 163.

34. Litun, P. P., Kyrychenko, V. V., Petrenkova, V. P., Kolomatska, V. P. (2009). Systematychnyi analiz v selektsii polovykh kultur. Kharkiv, 354.

35. Tsarenko, O. M., Zlobin, V. H., Skliar, Yu. A., Panchenko, S. M. (2000). Computer methods in agriculture and biology. Sumy: TOV «Elita-Star», 203.

36. Liubych, V. V., Novikov, V. V., Leshchenko, I. A. (2019). Influence of the duration of dehusking and water heat treatment grain obtaining and culinary evaluation of wheat rolled cereal emmer. Scientific Notes of Taurida National V. I. Vernadsky University. Series: Technical Sciences, 30 (6 (69)), 107-111. doi: http://doi.org/10.32838/2663-5941/2019.6-2/19

37. Petrenko, V., Liubich, V., Bondar, V. (2017). Baking quality of wheat grain as influenced by agriculture systems, weather and storing conditions. Romanian Agricultural Research, 34, 69-76. Available at: https://www.cabdirect.org/cabdirect/abstract/20183008263

38. Kiseleva, M. I., Kolomiets, T. M., Pakholkova, E. V., Zhemchuzhina, N. S., Lubich, V. V. (2016). The differentiation of winter wheat (Triticum aestivum 1.) cultivars for resistance to the most harmful fungal pathogens. Sel'skokhozyaistvennaya Biologiya, 51 (3), 299-309. doi: http://doi.org/10.15389/agrobiology.2016.3.299eng 